\title{
WSPÓECZESNE OBRAZY GROZY - LEGENDY MIEJSKIE O DUCHACH Z TAJWANU I HONGKONGU
}

Legenda miejska (ang. urban legend) jest to pozornie prawdopodobna, choć zazwyczaj nieprawdziwa informacja rozpowszechniana w mediach, Internecie bądź w kręgach towarzyskich ${ }^{1}$. Zwie się ją też plotką bądź sensacja, współczesnym mitem, a nawet jest uważana za nowy gatunek prozy ludowej ${ }^{2}$. Miejska legenda fascynuje słuchaczy, prowokuje do dalszego jej przekazywania, dotyczy bowiem znanych osób i powszechnych zjawisk, a często przedstawiane w niej zdarzenia są czymś, co każdemu może się przytrafić. Historie te są często przekształceniem wcześniejszych opowieści ludowych, np. korzeni sławnej w epoce PRL-u polskiej legendy o czarnych wołgach można upatrywać w historiach o Żydach bądź szerzej - obcych (także kosmitach) porywających dzieci. Współcześnie najpopularniejszym wariantem są opowieści o pedofilach dokonujących podobnych czynów, czyhając na swoje ofiary w centrach handlowych. Jednakże w czasie rozprzestrzeniania się danej miejskiej legendy powstaje wiele zmienionych wersji, w efekcie czego jej sensacyjny charakter powszednieje, a ona sama traci wiarygodność. Słysząc nawet coraz to nowy wariant, społeczność w końcu uodparnia się na konkretną historię.

Przyjmuje się, że legendę miejską można rozpoznać (zwłaszcza na tle innych fałszywych doniesień prasowych) na podstawie omówionych niżej cech.

1) Cykliczność - jeśli dana historia pojawia się w danym społeczeństwie cyklicznie, niejednokrotnie wywołując panikę, to możemy przypuszczać, że mamy do czynienia z legendą miejska.

2) Anonimowy autor - często historie zaczynają się od sformułowania: „Znajomy mojego znajomego opowiadał...”3, „To zdarzyło się naprawdę, ponieważ przeczytałem o tym..." itp. Narratorzy legend podejmuja liczne zabiegi, aby

1 D. Czubala, Wspótczesne legendy miejskie, Katowice 1993, s. 35. Nie wszyscy badacze jednak zgadzają się z tą definicją, zarzucając, że kryterium wiarygodności nie jest decydujące i postulując, by wprowadzić np. rozróżnienie między legendą miejską a plotką. W efekcie kwestia ostatecznej definicji legendy miejskiej pozostaje wciąż nierozwiązana, a badania nad nimi wciąż są uznawane za młode i nieujednolicone pod względem metodologicznym.

2 Ibidem, s. 9. W tym ujęciu legenda miejska byłaby kolejną formą ludowego gawędziarstwa obok anegdot, legend, baśni i podań.

3 M. Barber, Legendy miejskie, Warszawa 2007, s. 13. 
uwiarygodnić swoją opowieść, powołują się na media, sąsiadkę, która opowiadała im tę historię czy panią z kolejki w sklepie, a nawet na to, że sami byli jej świadkiem. Bywają też tacy, którzy demonstrują swój mniej lub bardziej sceptyczny stosunek do przytaczanej historii i opowiadaja ją raczej jako ciekawostkę. Najczęstszym bodajże autorem doniesień jest „znajomy znajomego” - niejednokrotnie niemożliwy jednak do zidentyfikowania. Osoba ta bowiem albo nie pamięta takiej opowieści, albo okazuje się, że nie miała z nią nic wspólnego. Ostatecznie więc nie wiadomo, kto był prawdziwym świadkiem zdarzenia i autorem historii. Tak samo dzieje się w przypadku próby odnalezienia pierwotnego źródła w Internecie lub prasie - często okazuje się, że nie możemy go odszukać, choć moglibyśmy przysiąc, że o tym gdzieś przeczytaliśmy.

3) Pozorna autentyczność - legendy miejskie cechują się względnym prawdopodobieństwem, które jest wzmacniane np. poprzez umiejscowienie akcji danej legendy lokalnie ${ }^{4}$. Może to być np. najbliższa kebabiarnia, którą zarówno my, jak i nasz słuchacz często bądź niedawno odwiedzaliśmy. Sam opowiadający także może dodawać autentyczności opowieści poprzez fakt, że w nią wierzy, przez co jego historia wydaje się bardziej autentyczna.

4) Szybkie rozprzestrzenianie się - najczęściej w formie ustnej, ale dzisiaj także za pośrednictwem Internetu ${ }^{5}$.

5) Lęki społeczne - główny temat legend miejskich dotyka bieżących problemów, niepokojów i uprzedzeń społecznych, które dominują w danym okresie w społeczeństwie ${ }^{6}$. Często takie lęki są jednak o wiele starsze niż samo zjawisko legend miejskich, dlatego nawet bardzo stare motywy powracają w swojej odświeżonej formie, zastępując np. archaizmy zaawansowaną technologia (samochody zamiast furmanek itd.).

Im więcej z wymienionych cech dana opowieść zawiera, tym bardziej możemy być pewni, że mamy do czynienia właśnie z legenda miejską. Można nawet przyjać, że niewątpliwie dane zdarzenie jest legenda, jeśli w krótkim czasie informacja taka pojawiła się wielokrotnie w oddalonych od siebie miejscach.

Wśród znanych badaczy legend miejskich należy z pewnością wymienić Jana Harolda Brunvalda, Paula Smitha, Bengta af Klintberga i wielu innych ${ }^{7}$, a wśród pozycji

\footnotetext{
4 Ibidem, s. 12.

5 Niektórzy badacze zaliczają tu również tzw. folklor internetowy, choć nie jest on tożsamy z legendą miejską. Ibidem, s. 14-15.

6 Ibidem, s. 12.

7 Zob. J.H. Brunvald, The Vanishing Hitchbiker: American Urban Legends and Their Meanings, New York 1981; idem, The Choking Doberman and Other „New” Urban Legends, New York 1984; idem, The Mexican Pet: „New” Urban Legends and Some Old Favorites, New York 1988; Contemporary Legend: A Reader, eds. G. Bennett, P. Smith, New York 1993; Urban Legends: A Collection of International Tall Tales and Terrors, eds. G. Bennett, P. Smith, Westport 2007; B. af Klintberg, Råttan i pizzan [Szczur w pizzy], Stockholm 2001; idem, Den stulna njuren [Znikająca nerka], Norstedt 1994; M. Barber,
} 
publikowanych bądź pisanych po polsku należałoby wymienić Marka Barbera czy Dionizjusza Czubalę. Według Czubali wśród współczesnych legend miejskich można wyróżnić chociażby takie kategorie, jak legendy polityczne, medyczne czy samochodowe ${ }^{8}$.

\section{Legendy o środkach transportu}

Jednym z najsłynniejszych motywów kojarzonych z legendami miejskimi jest historia o znikającym autostopowiczu. Opowieść ta stała się powszechnie znana po publikacji książki The Vanishing Hitchbiker autorstwa Jana Harolda Brunvalda w 1981 r., która przyczyniła się do wzrostu świadomości społecznej na temat legend miejskich. Opowieść ta jest typowym przykładem legendy samochodowej i można ja spotkać na całym świecie, wszędzie, gdzie występują samochody i długie trasy ruchu, więc nic dziwnego, że opowiadana jest również w Azji. Sam Brunvald uważa, że legenda ta wykazuje największą elastyczność spośród wszystkich motywów, stąd jej niesamowita popularność w różnych kulturach ${ }^{9}$. Czasem pojawia się nawet w takich miejscach na świecie, gdzie zjawisko podwożenia autostopowiczów nie jest zbyt popularne (Chiny, Japonia) albo nawet wcale nie występuje, jak np. w Indiach ${ }^{10}$. Możliwe, że właśnie dlatego historie z tym motywem przydarzają się w Azji głównie kierowcom taksówek. Poniżej wersja ze stolicy Tajwanu, Tajpej.

\section{Znikajacy autostopowicz. (Tajwan)}

Działo się to podczas Miesiąca Duchów, w który Yi nigdy nie wierzył. W tym czasie przemierzał przedmieścia Tajpej - gdzieś blisko gór, choć było już po północy. Był taksówkarzem, ale tej nocy nie miał klientów. Nagle usłyszał z tylnego siedzenia pytanie zadane kobiecym głosem: „Dokąd jedziesz?”, a w lusterku zobaczył kobietę na tylnym siedzeniu. Nie mógł zrozumieć, skąd się tam wzięła i zaczął podejrzewać, że ma zwidy z przemęczenia. Obejrzał się przez ramię, ale ona naprawdę tam była. Dlatego też spytał ją: „A dokąd pani chce jechać?”, na co ona odpowiedziała: „Do Nangang”.

Zawiózł ją tam, a ona chciała mu zapłacić, podając mu papierowe pieniądze przeznaczone dla zmarłych [zwane też piekielną walutą - A.S.]. Gdy je zobaczył, przypomniały mu się ostrzeżenia kolegów, by nigdy nie akceptować takiej zapłaty, bo można ściągnąć na siebie kłopoty i duchy. Oznajmił więc, że nie chce zapłaty

W. Orliński, Legendy miejskie, Warszawa 2007; D. Czubala, Wspótczesne legendy...; idem, Wokót legendy miejskiej, Bielsko-Biała 2005; idem, Polskie legendy miejskie, Katowice 2014.

D. Czubala, Wspótczesne legendy...

J.H. Brunvald, The Vanishing Hitchbiker..., s. 24.

10 Zob. M. Lyngdoh, The Vanishing Hitchbiker in Shillong: Khasi Belief Narratives and Violence Against Women, „Asian Ethnology” 2012, vol. 71, no. 2. 
i w tym momencie kobieta zwyczajnie rozpłynęła się w powietrzu, mimo że nawet nie zdążył zwolnić ani się zatrzymać, by ją wypuścić z samochodu.

W ciagu najbliższych dni wielu innych taksówkarzy opowiadało podobne historie, a niektórzy z głupoty zaakceptowali zapłatę. Yi uznał to za nauczkę, by nigdy nie zostawiać zapalonego światła $z$ informacja o wolnej kabinie, gdy jedzie przez pustkowie, zwłaszcza podczas Miesiąca Duchów ${ }^{11}$.

Przytoczona opowieść ma wiele cech typowej legendy o znikającym autostopowiczu: mamy w niej motyw człowieka jadącego samochodem, który spotyka tajemniczego nieznajomego. Gdy tylko dojeżdża do wskazanego przez niego miejsca, okazuje się, że ten znikł bez śladu ${ }^{12}$. Nie znaczy to jednak, że akcja wszystkich legend o autostopowiczu rozwija się tak samo ${ }^{13}$. W tej również mamy wiele nowych elementów, chociażby kierowcę taksówki, a także azjatyckie zwyczaje kulturowe (wspomniany Miesiąc Duchów, papierowe imitacje pieniędzy dla zmarłych). W wielu innych miejscach Azji opowiada się bardzo podobne historie, które różnią się jedynie miejscami początkowymi i docelowymi podróży, np. w Singapurze zawsze podczas Miesiąca Duchów powtarzana jest opowieść o duchu-znikającym autostopowiczu ${ }^{14}$. Zazwyczaj zjawa zmierza we wskazane przez siebie miejsce w konkretnym celu: wraca na cmentarz, miejsce wypadku, gdzie zginęła, do domu, w którym mieszkała za życia, czasami nawet ma ważny powód, by się pojawić, np. rocznicę własnej śmierci ${ }^{15}$. Choć niektórzy badacze twierdzą, że w legendzie miejskiej musi zawsze pojawić się element wyjaśnienia całego zdarzenia, to w przypadku azjatyckiej odmiany znikającego autostopowicza nie zawsze warunek ten jest spełniony ${ }^{16}$.

11 Źródło: Three Ghost Stories for Ghost Month, http://www.theworldofchinese.com/2014/08/ three-ghost-stories-for-ghost-month/ (dostęp: 13.04.2018); Chinese folktales, myths, legends, and proverbs, translated, adapted, and annotated by F. Lobb, http://chinesefolktales.blogspot.com/ (dostęp: 8.05.2015). W przypadku tej historii później informator przyznał się rozmówcy, że ja zmyślił. Jednakże podobne historie pojawiają się w całej Azji i różnią się praktycznie tylko miejscem akcji. Bardziej prawdopodobne w tym przypadku jest, że informator nie do końca wierzył w prawdziwość przytoczonej przez siebie historii (możemy go więc traktować jako autora sceptycznego), którą jednak na pewno skądś wcześniej usłyszał.

12 D. Czubala, Wspótcžesne legendy..., s. 36. Najczęściej autostopowicz okazuje się duchem albo seryjnym morderca.

${ }^{13}$ W zbiorze legend miejskich Marka Barbera to młoda dziewczyna wracająca samotnie samochodem w nocy jest bohaterką wydarzeń, autostopowicz w żadnym wypadku nie pyta jej o podwiezienie. Zwykle jest to seryjny morderca, który stanowi dla niej bezpośrednie zagrożenie i ukrywa się w jej samochodzie na tylnym siedzeniu. Ten wariant legendy pochodzi z Anglii. Jej zadaniem jest ostrzeżenie młodych kobiet, by uważały po ciemku na drodze, gdyż samochód nie chroni przed obcymi.

${ }^{14}$ A Month of Hungry Ghosts (Singapore Ghost Month Documentary), Mythopolis Pictures 2008.

15 D. Czubala, Wspótczesne legendy..., s. 36.

16 Występował zawsze w podaniach ludowych, w których możemy upatrywać genezy azjatyckiej opowieści o znikającym autostopowiczu, np. The Old Coffin Maker, http://chinesefolktales. blogspot.com/2015/08/the-old-coffin-maker-vanishing.html (dostęp: 3.04.2018). 
Jednak opowieści te wykazują podobne cechy: często taksówkarz przejeżdża niedaleko miejsc o niskim zaludnieniu, złej renomie, po pustkowiach, gdzieś na przedmieściach bądź w okolicach cmentarza. Historia o znikającym autostopowiczu corocznie przeżywa swój nowy cykl podczas obchodów Miesiąca Duchów w Azji, ale zdarzają się też wyjątki od tej reguły, związane np. z niedawnymi tragediami1 ${ }^{17}$.

Główny motyw tej opowieści naukowcy próbują tłumaczyć jako wynik halucynacji związanych z długą samotna jazdą jednostajną drogą szybkiego ruchu w nocy, kiedy oczy ciagle skupione na jednym punkcie zaczynaja już niedomagać, a organizm potrzebuje odpoczynku. Najczęściej takie sytuacje w Ameryce przytrafiają się kierowcom ciężarówek, jednakże to nie oni są bohaterami legendy miejskiej o autostopowiczu.

\section{Jeszcre mi nie dziekuj (I wersja, Tajwan)}

Pewnego dnia znajomy jechał samochodem wraz ze swoją dziewczyną. Jechali bardzo długo, ale przez większą część drogi nic specjalnego nie spotkało ich po drodze. Dziewczyna znużona długą jazdą zaczęła przysypiać na siedzeniu pasażera i jej chłopak też już był zmęczony. W pewnym momencie zaczęli krążyć w kółko i stało się jasne, że zgubili drogę. Dziewczyna zaczęła dawać swojemu chłopakowi wskazówki, dokąd ma jechać. Jednak w pewnym momencie usłyszał jej przestraszony głos: „Uważaj, zaraz spadniemy z klifu!”. W ostatniej chwili chłopakowi udało się zatrzymać samochód i gdy się wychylił do przodu, zauważył, że stanął na samym skraju klifu - dosłownie parę centymetrów dalej i spadliby w przepaść. Kiedy przestraszony odwrócił się do swojej dziewczyny, zorientował się, że jego towarzyszka cały czas spała. Zdziwiony, usłyszał nagle za plecami głos: „Gdybyśmy tylko umarli razem..."18.

Jest to jedna z wielu wersji legendy, a można ją rozpoznać po charakterystycznych cechach wspólnych, takich jak klif i przestrzegający głos kobiecy, który okazuje się zwodniczy. Czasem występuje w niej motyw kobiecej sylwetki lub kobiety w czerwieni, który zostanie omówiony w dalszej części artykułu. Choć w żadnej znalezionej wersji nie jest to jednoznacznie napisane, możemy założyć, że historia

17 Telegraph News, https://www.telegraph.co.uk/news/worldnews/asia/japan/12111749/ Taxi-drivers-in-tsunami-disaster-zone-report-ghost-passengers.html (dostęp: 5.04.2018). Takie przypadki miały miejsce po trzęsieniu ziemi i tsunami w Japonii w 2011 r. Podczas tej tragedii wiele osób zginęło albo znikło bez śladu. Taksówkarze kursujący na trasach blisko regionu Tōhoku, który ucierpiał wtedy najbardziej, donosili o tajemniczych autostopowiczach - byli oni duchami ofiar tej katastrofy, które próbowały wrócić do domu i prosiły o dowiezienie ich w miejsca, gdzie - jak się potem okazywało - wcześniej mieszkały. Po dojechaniu do celu znikały bez wytłumaczenia z tylnich siedzeń samochodu.

18 Chinese folktales..., http://chinesefolktales.blogspot.com/2013/11/internet-ghost-stories-from-taiwan.html (dostęp: 10.04.2018). 
dzieje się po zmroku: bohater nie widzi dokładnie drogi i często dopiero po wyjściu z samochodu zauważa, że stoi na skraju klifu, co wskazuje na ograniczoną widoczność. Duchy pojawiaja się tradycyjnie właśnie po zmroku, dlatego większość chińskich legend samochodowych, w których są bohaterami, dzieje się wieczorną bądź nocną pora, gdzieś na odludziu.

\section{Zejscie do raświatów (Hongkong)}

Ludzie mówią że istnieje sekretne wyjście na ulicę Rumsey Street. Można za jego pomocą dotrzeć do stacji, na której nigdy nie zatrzymuje się żaden pociag. Nie miałby zreszta jak wjechać, gdyż wejście jest odgrodzone łańcuchami. Miejsce to jest nazywane „mała platformą" stacji Sheung Wan, a zostało odcięte od reszty linii metra, gdyż pracownicy donosili o tym, że objawiała się tam kobieta w białych szatach, która unosiła się w powietrzu i rzucała na tory. Słychać było również jęki dochodzace $z$ tunelu w środku nocy. Przestraszeni pracownicy zaczęli się obawiać, że otwarli przejście do zaświatów bądź bramy piekieł, sprowadzili więc buddyjskiego mnicha, by odprawił rytuał, a następnie zamknięto platformę ${ }^{19}$.

\section{Historia ₹ Tsuen Wan (Hongkong)}

Na wielu stacjach na linii metra Tsuen Wan często można było spotkać duchy zmarłych. Choć zgłaszano osoby popełniające samobójstwa na tej trasie, to nie można było znaleźć szczątków samobójców na torach, jakby rozpłynęli się w powietrzu. Czasem pracownicy metra donosili, że widzą na torach człowieka szukającego czegoś na czworaka. W takich przypadkach najczęściej udają że nikogo tam nie widzą lub ostentacyjnie patrzą w drugą stronę. Pewnego razu kierownik stacji zauważył mężczyznę, który wszedł na tory, więc natychmiast zwrócił mu uwagę i spytał, co tam robi. Mężczyzna spojrzał na niego z dołu i odparł: „Szukam moich stóp!”. Wtedy kierownik spojrzał w dół i zobaczył, że faktycznie człowiek ten nie tylko nie miał stóp, ale także całej połowy ciała poniżej pasa. $\mathrm{Na}$ jego oczach postać rozpłynęła się w powietrzu. Kierownik doznał szoku i musiał poddać się terapii. Gdy udało mu się ją pomyślnie zakończyć, poprosił o zmianę dyżuru na stacji na wcześniejszą godzinę, na którą to propozycję jego pracodawcy przystali ${ }^{20}$.

Stacje metra, dworce i wszelkiego rodzaju przystanki sa przykładami miejsc liminalnych, tj. miejsc progowych, znajdujących się pomiędzy dwoma różnymi miejscami, a czasem wręcz światami. Podróżując pomiędzy nimi, każdy jest narażony na niebezpieczeństwo. Środki masowego transportu nie są go pozbawione. Dlatego

19 Chinese folktales..., http://chinesefolktales.blogspot.com/2014/09/contemporary-ghost-stories-from-china.html (dostęp: 4.04.2018).

20 Ibidem. 
w podróży często widuje się duchy i inne zjawiska nadnaturalne. Legendy miejskie zwykle dotyczą bardzo starych dworców i miejsc (np. metra w Nowym Jorku lub w Londynie). Teoria ta nie sprawdza się w przypadku chińskich stacji, gdyż często nowo wybudowane dorabiają się własnych historii o duchach, czego przykładem są przytoczone opowieści z Hongkongu. Stacje stają się swego rodzaju przejściem do innego świata. Pojawiało się tam wiele duchów, zaczęto nawet mówić o nieistniejącej stacji - „bramach do piekła”. Często duchy są związane z miejscem swojej śmierci, a rozmowy z nimi przynoszą pecha.

\section{Legendy o kobiecie w czerwieni}

Zjawy kobiet w czerwonym stroju są uważane za najbardziej niebezpieczne, wredne i mściwe duchy. Sama postać kobiety w czerwieni jest również charakterystyczna dla chińskiego folkloru i pochodzi od zjawy zwanej Nu Gui. Jest to zazwyczaj ubrany w białą, a czasem też czerwoną szatę duch samobójczyni lub ofiary morderstwa, która prowadziła się niemoralnie za życia lub była ofiarą przemocy seksualnej. Poszukuje ona zemsty na swoich oprawcach, zaś kobiety tylko straszy. Swego czasu znana była plotka o rodzicach, którzy pochowali swoją zamordowaną córkę w czerwonej sukience właśnie po to, by zemściła się po śmierci ${ }^{21}$. Czasem uznawana jest też za chińskiego odpowiednika sukkuba, gdyż jej celem bywają młodzieńcy, których uwodzi w celu wyssania z nich męskiej energii życiowej yang. Najczęściej Nu Gui są przywiązane do miejsca swojej śmierci.

Jest to wielokrotnie powracający motyw w chińskich legendach miejskich, zwłaszcza w opowieściach o różnego rodzaju środkach transportu, np. w cytowanej niżej legendzie samochodowej. Znaczenie ma tutaj także sam kolor czerwony, który w chińskiej tradycji jest związany właśnie ze złymi duchami, zemsta, tabu, odpędzaniem zła, ale też energią życiową, błogosławieństwem, szczęściem, radością i życiem, czyli wszystkim tym, czego mściwy duch nie ma i czego może zazdrościć ludziom ${ }^{22}$.

\footnotetext{
${ }^{21} \mathrm{~W}$ przytoczonej historii mamy do czynienia ze złamaniem pewnego tabu, gdyż zmarłych nie wolno chować w czerwonym stroju - jest to kolor zarezerwowany dla żywych i najczęściej kojarzony ze szczęściem. W zaświatach wszystko jest „na odwrót”, możliwe, że to także jeden z powodów, dla których kolor czerwony jest niewskazany dla zmarłych. Zob. S.F. Teiser, Ghosts and Ancestors in Medieval Chinese Religion: The Yü-lan-p'en Festival as Mortuary Ritual, „History of Religions" 1986, vol. 26, no. 1.

22 Wu Lan, Kultura chińskiego koloru - symbolika czerwieni, „Gdańskie Studia Azji Wschodniej” 2017, z. 12, s. 136-141. Tego rodzaju zazdrość nazywana jest mianem „zapalenia spojówek”, co także wiąże się z kolorem czerwonym. Ibidem, s. 135.
} 
Grupa przyjaciół jedzie samochodem późna porą gdy nagle przed maskę wybiega im kobieta w czerwieni²3 ${ }^{23}$ W ostatniej chwili zatrzymują samochód, wychodzą zobaczyć, czy ją potrącili i okazuje się, że kobiety nie ma, a oni stanęli na samym skraju klifu. Dochodzą do wniosku, że był to duch osoby, która zmarła, spadając z tego miejsca, dlatego próbowała ich ostrzec $i$ uratowała im życie. Już zaczynaja jej dziękować, gdy nagle słyszą szept za swoimi plecami: „Powinniście byli wszyscy umrzeć”24.

Jest to druga wersja przytaczanej wcześniej legendy samochodowej. Prawdopodobnie również w przypadku pierwszej opowieści możemy mieć do czynienia z tym samym mściwym duchem - co prawda, nie widzimy go, ale najwyraźniej opętał on dziewczynę śpiącą na siedzeniu pasażera, dlatego użył jej głosu, by ostrzec przed upadkiem z klifu. Kobieta w czerwieni pojawia się również w jednej z licznych wersji legendy o autobusie po północy ${ }^{25}$.

\section{Dřewcryyna w czerwieni (Hongkong)}

W latach 80. na stacji metra Yau Mai Tei w Hongkongu samobójczyni rzuciła się na tory, ale nigdy nie znaleziono jej ciała. Na tym jednak legenda się nie kończy. Jednym ze świadków zdarzenia była kobieta, która wkrótce pochorowała się i zmarła. Przed swoją śmiercią wyznała, że tamtego dnia miała na sobie dokładnie takie samo ubranie co samobójczyni i tę samą fryzurę, a twarze obu kobiet były bliźniaczo podobne ${ }^{26}$.

Podobna legenda krążyła na temat stacji Caobao w Szanghaju, gdzie samobójczyni ubrana w czerwoną sukienkę była widywana parę dni po swojej śmierci ${ }^{27}$. Ponoć siedziała zawsze w tym samym miejscu w późnych godzinach nocnych.

\section{Mała dziewcrynka o rozcietych ustach (Tajwan)}

Wersja I (Neipu, rejon Pingtung): Pewnego wieczoru dwóch kolegów wracało późno do domu, gdyż wybrali się skuterami do gorących źródeł. W drodze powrotnej jeden popędzał drugiego: „Jedź szybciej! Pośpiesz się!”. Obaj przyspieszyli, chociaż drugi kolega nie rozumiał, co się dzieje. Pędzili tak całą drogę. Zanim wrócili

\footnotetext{
${ }^{23}$ W innych wariantach jest to „kobieta cała we krwi” - nawet jeśli nie jest dosłownie ubrana w czerwoną sukienkę, czerwień nadal pozostaje jej znakiem rozpoznawczym.

${ }^{24}$ Chinese folktales..., http://chinesefolktales.blogspot.com/2013/11/internet-ghost-stories-from-taiwan.html (dostęp: 2.04.2018).

25 Bejiing's Bus Route 375, http://lenalesca.tumblr.com/post/39826756939 (dostęp: 2.04.2018).

26 Chinese folk.tales..., http://chinesefolktales.blogspot.com/2014/09/contemporary-ghost-stories-from-china.html (dostęp: 4.04.2018).

27 Shanghai's Haunted Train Station, 19.11.2011, http://weirdthings.com/2011/11/shanghais-haunted-train-station-weird-china/ (dostęp: 4.04.2018).
} 
do swoich domów, zatrzymali się przed lokalną świątynią Mazu ${ }^{28}$. Kolega w końcu zapytał, co się dzieje: „Co się stało? Dlaczego się tu zatrzymujemy?”. Jego towarzysz odparł: „Coś złego wydarzyło się w gorących źródłach. Już gdy tam byliśmy, czułem się jakoś dziwnie. Gdy zaczęliśmy wracać, usłyszałem bardzo niepokojący dziewczęcy śmiech. Odwróciłem się i zobaczyłem coś, czego wolałbym nigdy nie zobaczyć". Opowiedział, że podążała za nimi dziewczyna ubrana w czerwień, a w zasadzie sunęła w powietrzu, nie miała oczu tylko podłużne wycięte otwory w ich miejscu, nie miała też nosa, a jej usta były rozcięte od ucha do ucha, po jej twarzy spływały gęste strugi krwi ${ }^{29}$.

II wersja (Tainan): Dwie kobiety jadą na jednym skuterze późnym wieczorem, szukając konkretnej ulicy. Błądzą po osiedlu i okolicach kwatery zwanej jako „Nowa X”, nie mogąc jej znaleźć. Choć jedna z nich urodziła się w tej okolicy, nie jest w stanie rozpoznać osiedla. W końcu zauważaja stojąca przy ulicy małą dziewczynkę z pochyloną głową, która wygląda, jakby płakała. Zaniepokojone widokiem dziecka samego w nocy, podjeżdżają do niej bliżej i pytają, czy wszystko w porządku. W tym momencie dziewczynka zanosi się śmiechem i patrzy im w twarz. Wówczas ich oczom ukazuje się makabryczny widok - usta dziecka są rozcięte od ucha do ucha, a z rany sączy się świeża krew. Kobiety w panice natychmiast odjeżdżają na skuterze. Kiedy oglądają się za siebie dopiero dwa bloki dalej, widzą, że dziewczynka goni je z nożem w ręce, zanosząc się śmiechem. W końcu kobiety zatrzymują się w jednym z okolicznych sklepów 7-11 i tam spędzają całą noc, gdyż dziewczynka cały czas czeka na nie przed wejściem. Dopiero nad ranem, gdy pojawia się więcej klientów, mają odwagę wyjść ze sklepu. Po dziewczynce nie ma nawet śladu...

Później dowiedziały się, że osiedle, na które zajechały, kiedyś było miejscem egzekucji i jest znane z tego, że dzieją się tam niebywałe rzeczy. Otwarto tam knajpki popularne wśród pracowników fizycznych. Wielu klientów donosi, że ma wrażenie, jakby ktoś ich obserwował, słyszą dziwne odgłosy albo widzą przedmioty spadające na ziemię bez powodu. Czasem słyszą, jak ktoś ich woła po imieniu, należy wtedy odpowiedzieć, ale nie wolno się odwrócić. Jeśli się odwróci, można skończyć z wysoką gorączką na ostrym dyżurze. W teatrze w tej dzielnicy ktoś został zaczepiony przez bardzo małego człowieczka, z kolei ktoś inny widział osobę kapiąca się $\mathrm{w}$ fontannie pełnej $\mathrm{krwi}^{30}$.

Legenda o kobiecie z rozciętymi ustami przypuszczalnie została zaimportowana $z$ Japonii wraz z adaptacja tej opowieści w formie filmu grozy Kuchisake Onna z 2007 r., i w ten sposób zyskała popularność. Jednakże tytułowa kobieta z legendy

\footnotetext{
28 Mazu, oryginalnie bóstwo morza, dzisiaj na Tajwanie jest uważane za uniwersalne i popularne bóstwo ochronne. P.R. Katz, Religion and the State in Post-War Taiwan, „The China Quarterly” 2003, vol. 174, s. 395.

29 Chinese folktales..., http://chinesefolktales.blogspot.com/2013/11/internet-ghost-stories-from-taiwan.html (dostęp: 3.04.2018).

30 Ibidem.
} 
różni się od swojej oryginalnej wersji. W Japonii jest to kobieta w długim płaszczu z maseczką alergiczną na twarzy, zasłaniająca jej nietypową „kondycje”. Pyta znienacka ludzi, czy jest piękna, odsłaniając przy tym swoją oszpeconą twarz - bliznę wokoło rozciętych ust, sięgająca od ucha do ucha. W przypadku otrzymania niesatysfakcjonującej odpowiedzi potrafi zabić zaczepionych przechodniów. Chiński „sobowtór” opisywany jest za to jako postać ze świeżą raną, a czasem wręcz bez nosa, bez oczu, w miejscu ust ma nie tyle rozcięcie, ile pusty otwór, z którego ciagle sączą się całe strugi krwi, tak że cała dolna część jej twarzy wydaje się jedną wielką brocząca raną. Jest też ubrana w czerwień, co upodabnia ją do innej popularnej postaci z chińskich legend miejskich - kobiety w czerwieni. W tym miejscu nasuwa nam się kolejna interpretacja koloru czerwonego jako symbolu niezwykłej urody. Znaki określające czerwień występują w takich wyrażeniach, jak „kobieta w pięknym stroju”, „piękność”, „piękne kobiece oblicze”31.

Choć amerykański kolekcjoner i tłumacz podań ludowych Fred Lobb upatruje podobieństw tej legendy do japońskiej opowieści o Nopperabō bądź do chińskich goblinów, można też zauważyć, że z wyglądu jej bohaterka bardziej przypomina postacie z chińskiego folkloru, takie jak duch bez żuchwy, co wskazuje, że jej ciało znajduje się w fazie rozkładu ${ }^{32}$.

Duch bez żuchwy to tylko jeden z licznych przykładów kategorii tzw. głodnych duchów. Mogą się nimi stać ludzie, którzy zmarli samotnie, nie mając rodziny, samobójcy czy topielcy, umierający nagle, gwałtownie ${ }^{33}$ lub w odosobnionych miejscach, niezamężne kobiety. Nie otrzymują oni darów ani symbolicznych ofiar od swojej rodziny, dlatego stają się mściwymi, złymi duchami. W folklorze ich wygląd jest opisywany jako szpetny: mogą być całe porośnięte włosami, mieć wielkie czarne zęby, szpiczaste głowy, czerwone włosy, czarne twarze, a czasem także nie mają nosa, ust, jamy ustnej bądź żuchwy. Pluja „zimną śliną”, wydychają piekielne wyziewy, pukają

31 Wu Lan, Kultura chinskiego koloru..., s. 137.

32 Cała grupa takich istot występuje chociażby w podaniu ludowym $O$ dwóch braciach $i$ duchu bez. żuchwy, zob. http://chinesefolktales.blogspot.com/2016/07/the-two-brothers-and-chinless-ghost-han.html (dostęp: 30.04.2018).

33 Szczególnie problematyczne były zawsze niezidentyfikowane kości ludzkie. Odnalezienie takich blisko miejsca zamieszkania mogło ściąnąć złego ducha, który nie doczekał się godnego pochówku. By złagodzić potencjalny gniew takiej istoty, na terenach wiejskich na Tajwanie poświęcano im specjalną małą świątynię i składano w niej ofiary. Z czasem taki duch mógł przerodzić się w bóstwo opiekuńcze danego miejsca (J.L. Watson, Anthropological Analyses of Chinese Religion, „The China Quarterly” 1976, vol. 66, s. 363). Każdy głodny duch, któremu ludzie poświęcali czas i uwagę, miał na to szansę. Przypuszczalnie jednak nie da się zajmować wszystkimi nieszczęsnymi duszami, gdyż żywym nie starczyłoby na to czasu. Ten przykład pokazuje, że w chińskiej wizji zaświatów zmarli potrzebuja jednak pomocy żywych, by się odrodzić - z jednej strony jest to swego rodzaju obrzęd przejścia zmarłych, z drugiej strony przodkowie, którzy nie przejda go pomyślnie, gdyż np. nie otrzymują ofiar od swoich krewnych, mogą skończyć jako głodne duchy. Źródło: S.F. Teiser, Ghosts and Ancestors..., s. 52-55. 
do drzwi, gwiżdżą, wydają z siebie „śmiech nie z tego świata"34. Niektóre z cech tego opisu odpowiadają wyglądowi „kobiety z rozciętymi ustami”. Może to stanowić dowód na pewną ciagłość chińskiego folkloru zachowaną we współczesnej jego odmianie - legendach miejskich.

Ważną kwestią jest też płeć - kobieta w czerwieni, choć uważana za mściwego ducha, może zwyczajnie nie mieć innego wyjścia. Według chińskiej tradycji kobieta zwykle stawała się częścią rodziny męża. Jeśli zmarła przed ślubem, nie mogła zostać należycie pochowana, a jej tabliczka z imieniem pośmiertnym nie mogła stać na ołtarzyku w domu jej rodziców ${ }^{35}$. Zmarła stawała się więc niespokojnym duchem, niemającym swojego miejsca po śmierci. Ponownie symbolika koloru czerwonego może pomóc nam w interpretacji, gdyż czerwień jest też kojarzona z ceremonią ślubną ${ }^{36}$. Nie dziwi więc, że niezamężną bądź zmarłą tuż przed ślubem młodą kobietę reprezentuje czerwona (w domyśle: ślubna) suknia, której nie dane jej było włożyć. Suknia ta podkreśla liminalny status kobiety - w końcu nie dopełniła obrzędu przejścia, który w wielu kulturach definiuje kobiecość. Jeśli dodatkowo straciła życie w nieszczęśliwym wypadku lub popełniła samobójstwo, prawdopodobnie oznaczało to brak ratunku dla jej duszy. Na podstawie przytoczonych legend miejskich można łatwo zauważyć, że duchy w większości przypadków ${ }^{37}$ były młodymi kobietami, samobójcami lub osobami zmarłymi nagle, a więc zaliczano je do kategorii głodnych duchów.

\section{Współczesne tło kulturowe - Miesiąc Duchów}

Duchy są bardzo popularnym tematem w chińskich legendach miejskich. W Ameryce czy Japonii ten motyw jest także umiarkowanie popularny ${ }^{38}$, ale już np. w Polsce odsetek legend miejskich o duchach jest zdecydowanie niszowy, a dominujące

34 S.A. Smith, Talking Toads and Chinless Ghosts: The Politics of "Superstitious" Rumors in the People's Republic of China, 1961-1965, „The American Historical Review” 2006, vol. 111, issue 2, s. 417-418.

35 W niektórych rejonach Chin, w tym na Tajwanie i w Hongkongu, istniała tradycja tzw. małżeństw duchów, która miała zapobiegać takim sytuacjom. Rodzice po śmierci córki starali się znaleźć dla niej kandydata na męża - wśród żywych lub zmarłych. Następnie, po zgodzie wypatrzonej osoby, odprawiano rytuał symbolicznych zaślubin. Tabliczka imienna córki mogła więc zostać postawiona na ołtarzyku rodzinnym męża, a duch dziewczyny znaleźć w końcu swoje ostateczne miejsce spoczynku. Zob. D. Martin, Chinese ghost marriage, „JASO Occasional Papers” 1991, no. 8.

36 Wu Lan, Kultura chińskiego koloru..., s. 136.

$37 \mathrm{~W}$ pozostałych opowieściach po prostu nie wiemy niczego o sytuacji duchów przed ich śmiercią i pozostają nam tylko domysły.

38 Zob. A. Kharchenko, Tradycja i wspótczesność japońskiego folkloru: elementy wierzeń ludowych w japońskich legendach miejskich [w:] W kregu wartości kultury Japonii. W 140. rocznice urodżin Nishidy Kitarō (1870-1945), red. A. Kozyra, Warszawa 2013. 
historie dotycza raczej tematyki jedzenia, medycyny, znanych ludzi, uprzedzeń lub perypetii miłosnych. Może nas to skłaniać do wysunięcia hipotezy, że popularność tego motywu wynika z kultury, dlatego spróbuję osadzić te historie w głębszym kontekście społecznym.

W niektórych, choć nie we wszystkich opowieściach pojawia się wspomnienie o Miesiącu Duchów, podczas którego rozgrywa się akcja np. w Znikajacym autostopowiczu, gdyż wtedy najłatwiej jest spotkać istoty nadnaturalne. Święto Głodnych Duchów to tradycyjne święto zmarłych, które według kalendarza księżycowego przypada na piętnasty dzień siódmego miesiąca (zwykle jest to lipiec bądź sierpień, w 2018 r. święto wypadnie 25 sierpnia, zaś sam Miesiąc Duchów rozpocznie się 11 sierpnia i zakończy 9 września). Genezę powstania tego święta przypisuje się taoistycznemu mnichowi Bukongowi, który żył w VIII w., a sam rytuał łączy taoistyczne i buddyjskie wierzenia ${ }^{39}$.

W czasie tego miesiąca duchy zmarlych przybywają z zaświatów na 30 dni i odwiedzaja żyjących. Pierwszego dnia otwierają się bramy piekieł, co często sygnalizowane jest np. burzą lub piorunami. Obchodzi się go na cmentarzach, ale także w domach. Sposób obchodów bywa różny w zależności od regionu, ale często puszcza się na wodę małe trzcinowe łódki z lampionami, które wyznaczają zagubionym duchom kierunek z powrotem do krainy umarlych, a przed tabliczkami przodków lub przed domem spala się papierowe imitacje podarunków dla zmarłych (zwykle są to imitacje papierowych pieniędzy, najczęściej yuanów, ale czasami także dolarów, wśród różnych imitacji podarunków moga znaleźć się też papierowe ubrania, zegarki, komórki, laptopy i inne przedmioty codziennego użytku - wszystko, czego zmarły mógłby potrzebować).

Co istotne, na ziemię nie wracaja jedynie nasi przodkowie, ale też wszystkie zagubione i nieraz wrogo nastawione istoty zwane głodnymi duchami, dlatego często okres ten zwany jest także Miesiącem Głodnych Duchów. Jak wspomniano, są to duchy, które popełniły przewiny za życia lub które nie maja już własnej rodziny bądź nie zostały należycie pochowane ${ }^{40} \mathrm{i}$ błąkają się w tym czasie bez celu po świe-

39 Genezy tradycji Miesiąca Duchów, jak również wiary w obecność zmarłych w określonych okresach roku możemy upatrywać w o wiele starszej tradycji marszu z trupami. Zwyczaj ten polegał na prowadzeniu ciał zmarłych do ich rodzinnych wiosek. Wierzono bowiem, że człowiek po śmierci powinien wrócić tam, gdzie się urodził i skąd pochodził, gdyż z tą ziemią związane były jego ciało i dusza. Jeśli nie zdołał tego dokonać, to jego dusza błąkała się w nieskończoność po świecie żywych - stawał się głodnym duchem albo istotą im podobną. Od dawna ludzie migrowali w poszukiwaniu zarobków, dlatego też często mieszkali gdzie indziej niż się urodzili i trzeba było ich ciała przetransportować. Zajmował się tym profesjonalny taoistyczny mnich (czasem zwany także specjalista feng-shui), chodził po wioskach i „zbierał” ciała zmarłych, by przenieść je w odpowiednie miejsce.

40 Selina Ching Chan, Heritagizing the Chaozhou Hungry Ghosts Festival in Hong Kong [w:] Chinese Cultural Heritage in the making. Experiences, negotiations and contestations, eds. M. Svensson, Ch. Maags, Amsterdam 2018, s. 153. 
cie ludzkim, wciąż cierpiąc niezaspokajalny głód. W intencji tych dusz odprawia się specjalne rytuały, a także zostawia ołtarzyki, np. na skrzyżowaniach dróg, z boku na chodnikach (składa się na nich papierowe imitacje darów, kadzidła oraz jedzenie) lub przed domem. Trzeba także uważać, by nie nastąpić na taki ołtarzyk, inaczej głodny duch może się na nas zemścićc ${ }^{41}$.

Podczas Miesiąca Duchów obowiązują pewne zasady, których należy przestrzegać, by nie okazać braku szacunku zmarłym oraz by nie przywiązać duchów do danego miejsca, gdyż jeśli zostaną w nim na dłużej, mogą przyciagną́ nieszczęścia $^{42}$. W tym czasie zwraca się do duchów słowami „nasi bracia/dobrzy bracia”³. W domu także można przyszykować swoim przodkom ucztę i zostawić dla nich puste krzesło przy stole ${ }^{44}$. W trakcie Miesiąca Duchów organizowane są różne publiczne uroczystości, często traktowane jako rozrywka poświęcona zarówno dla żywych, jak i zmarłych. Dla tych ostatnich często zostawia się pierwszy rząd krzeseł wolny. Miesiąc Duchów odgrywa też ważną rolę w chińskiej kulturze, spaja całą społeczność i wzmacnia poczucie kulturowej tożsamości ${ }^{45}$. Choć nie we wszystkich legendach miejskich akcja dzieje się podczas Miesiąca Duchów, możemy założyć, że właśnie wtedy najwięcej z nich przeżywa swój kolejny cykl. Większość takich zdarzeń ma miejsce po zmroku, na pustkowiach lub w okolicach mało zaludnionych.

Wierzenia związane z duchami i zmarłymi zajmują istotne miejsce w chińskiej kulturze. Chińskie legendy miejskie, tak jak w wielu innych krajach na świecie, odzwierciedlają niepokoje czy też opresje społeczne, są odbiciem danych czasów. W artykule przybliżyłam głównie legendy miejskie o duchach i nawiedzonych środkach transportu.

${ }^{41}$ W dokumencie o obchodach Miesiąca Duchów w Singapurze pokazano osobę, która przez przypadek nastąpiła na dary dla głodnych duchów na skraju chodnika. Od tego czasu zaczęły się u niej bóle w nodze, a potem pojawiły się czarne plamy. Mimo pomocy lekarzy przypadłość nie ustępowała. Zdesperowana osoba udała się do specjalisty duchowego, który polecił przeprosić głodne duchy, ustawić nowy ołtarzyk i odprawić krótki rytuał. Dopiero po wykonaniu tych czynności objawy ustąpiły i chory wrócił do zdrowia.

42 Zaleca się ustawienie ołtarzyka na skrzyżowaniach dróg, by dobra passa przyszła z czterech kierunków, rozmawianie ze zmarłymi, bo w tym okresie mogą nas usłyszeć, obowiązują też liczne przestrogi: 1) nie pływaj podczas Miesiąca Duchów - duchy mogą cię ściagnąć na dno, 2) nie wychodź po zmroku - jest to czas wędrówek duchów, 3) nie przeprowadzaj się - inaczej twoi przodkowie nie znajda drogi do domu, 4) nie otwieraj nowego biznesu, bo możesz przywiązać ducha do nowo otwartego miejsca, zostanie on na ziemi i będzie ściagał złą passę w interesach, odstraszał klientów itp., 5) nie zawieraj małżeństwa, gdyż może to przynieść pecha, poza tym traktowane jest jako nietakt i brak szacunku wobec zmarłych.

43 Inaczej mogłyby się obrazić, gdyż określenie „duch” jest nacechowane pejoratywnie. Zob. R.P. Weller, Bandits, Beggars, and Ghosts: The Failure of State Control over Religious Interpretation in Taiwan, "American Ethnologist” 1985, vol. 12, no. 1, s. 48.

44 Selina Ching Chan, Heritagizing the Chaozhou Hungry Ghosts..., s. 146-147.

45 Zob. J. DeBernardi, Space and Time in Chinese Religious Culture, „History of Religions” 1992, vol. 31, no. 3, s. 265-267. 
Są one zwykle ściśle związane z konkretnymi wydarzeniami lub okresami w roku. Ostatnimi laty popularne stało się zbieranie baśni i ludowych podań w Chinach w celu zachowania starych tradycji, a w przypadku legend miejskich można by zaryzykować stwierdzenie, że wiele z nich nosi cechy nowego folkloru, zwłaszcza że występuja w nich postacie przypominające bohaterów dawnych podań ludowych (co wydaje się zresztą wspólne dla całego obszaru Azji). Szczególnie ciekawe są przypadki wpasowywania się legend z innych obszarów do rodzimej kultury (chociażby Kuchisake Onna). Historie te moga być też przejawem tęsknoty za dawnym folklorem i wierzeniami.

Zdaję sobie sprawę, że zdołałam jedynie wstępnie zarysować temat chińskich legend miejskich. Wśród badaczy tego rodzaju folkloru jest to wciąż obszar niezbadany, przynajmniej na gruncie europejskim, i brak osobnego opracowania dotyczącego tej problematyki. W przypadku legend miejskich każda sfera życia (jak medycyna, jedzenie, gry komputerowe, polityka, a nawet teorie spiskowe) może znaleźć wyraz w podobnych historiach. Istnieje więc wiele interesujących obszarów w kwestii chińskich legend miejskich, które wciąż czekają na swoje odkrycie.

\section{SUMMARY}

\section{CONTEMPORARY DREADFUL GHOST TALES. URBAN LEGENDS FROM TAIWAN AND HONG KONG}

The main topic of this article is to examine Chinese urban legends - a field that is left unexplored in the European science. The author chooses to narrow the field of study only to ghost tales of Taiwan and Hong Kong, because of the limitation of space. There are two main categories of ghost legends: folklore about means of transportation (starting from car folklore and the famous The Vanishing Hitchbiker trope, but also the tales of haunted metro stations), and stories about the girl in red. Each category is represented by various tales and its many variations, as urban legends are rarely told the same way twice. In the article, the author proceeds to prove that urban legends are closely related to earlier Chinese folktales, especially the character in red. There are also many motives that seem to be common for the whole Asian culture, which tends to also have the custom of Ghost Month in common, which does not seem to be a coincidence in this case. The article closes on the note that seemingly popular Chinese ghost legends are perhaps an expression of nostalgia, or even suggest some sort of preserved continuity in Chinese folklore and traditional beliefs. 